\title{
The Role of Arbitration Clauses in Resolving Disputes in Carriage of Goods Across International Borders
}

\author{
Inetimi Mac-Barango \\ Faculty of Law, Niger Delta University, Wilberforce Island, Nigeria
}

\begin{abstract}
For the past decade or so, the uniformity of the law of international carriage of goods by sea has increasingly been undermined by the promulgation of hybrid carriage regimes by several maritime jurisdictions which depart from the established international uniform rules. This is one of the exemplifications of the increasing disregard for international maritime law propelled by accelerating domestic unilateralism. The aim of this article is to bring to the fore the role of arbitration in resolving disputes between parties in the international carriage of goods in juxtaposition with litigation, and why it is favoured among other alternative dispute resolution mechanisms. This paper argues that in the absence of a uniform set of laws regulating commercial disputes at sea, the inclusion of arbitration clauses in international carriage of goods is the most effective means of resolving disputes among parties. Not only does arbitration save time and cost, but also awards can be enforced on multiple jurisdictions.
\end{abstract}

Keywords: Arbitration, Arbitration Clauses, Dispute solving, International trade

DOI: $10.7176 / \mathrm{JLPG} / 83-04$

Publication date:March $31^{\text {st }} 2019$

\subsection{Introduction}

Arbitration can be defined as a non-judicial process for the settlement of disputes outside the law court. It is an alternative dispute resolution mechanism where an independent third party - an arbitrator - makes a decision (award) that is binding on the disputing parties. Arbitrations are mostly used in resolving commercial disputes, especially those of an international dimension. It has become the principal way of resolving disputes between states, individuals and corporations in almost every aspect of international trade, commerce and investment (Redfern et al 2008). While drawing up contractual terms, parties insert an arbitration clause in case of future disputes arising from the commercial transaction. While a party cannot unilaterally withdraw from arbitration, there are very limited rights of review and appeal of arbitration awards.

Wolaver (1983) enunciates that arbitration as a means of settling disputes started at the point in which man relinquished his rights to the state in exchange for security and protection. This is reminiscent of Jean Jacques Rousseau's Social Contract theory where the legitimacy of political authority and laws are only binding when they are supported by the general will of the people (Rousseau 2017). In view of this, arbitrations are only binding when they are supported by the will of the parties involved. Aristotle urged the benefits of conciliation, while in Heraldus' Animadversiones as observed by Wolaver (1983) there is an account of a court of reconcilement that existed among the Greeks. It is also common knowledge that the Romans used arbitration as a means of settling disputes in the $17^{\text {th }}$ century medieval Roman Empire (Redfern et al 2009). Whatever may be the case, it is evident from the foregone accounts that the use of arbitration as a means of settling disputes antedates formal legal systems.

Though traditional courts existed to resolve disputes, the commercial community never assented to their role in the settlement of business disputes. The predominant notion by guild merchants in the medieval era was that lawyers did not understand commercial problems as well as the technical and time-consuming nature of litigation which did not speedily resolve disputes. The idea of tribunals appealed to merchants because it allowed the privilege for company merchants to settle potential disputes without going through a court process. In effect, a solution was found in the charters were drafted between the merchants who recognized the need for some extra judicial method, preferring to seek justice 'according to the law of the merchants' instead of common law (Wolaver 1983) By the turn of the 18th century arbitration was solidly entrenched as an alternative means of dispute resolution within which judicial intervention now extensively occurs because of the natural desire of the courts to keep all adjudications within their sphere, or partly due to the fear of the growth of a new system of law.

While the core of arbitrations has largely remained the same i.e. the resolution of conflicts outside the law courts, its nature has changed over time to accommodate changing trends. What started as an avenue through which disputing local merchants could resolve their conflicts has metamorphosed into institutional laws assuming international dimensions. The United Nations Convention on Contracts for the International Carriage of Goods wholly or partly by sea (2008), UNCITRAL Model Law on International Commercial Arbitration (1985) and the 1958 New York Convention popularly known as Rotterdam Rules are examples. These institutional interventions are not only attempts at creating a uniform set of rules upon which arbitrations can be placed, but also lay to rest the legal definition of place.

In arbitrations, place (seat of arbitration) is important in preventing conflict of law and questions of 
jurisdiction. The determination of the place of arbitration prevents the parties from facing any complications that may arise from unforeseen circumstances at any stage in the arbitration proceedings. As such, as enshrined in UNCITRAL Convention on the Recognition and Enforcement of Foreign Arbitral Awards (adopted 10 June 1958), a well drafted arbitration clause should consider among other things the place of arbitration. The practical importance of designating the arbitration place is confirmed by model arbitration clauses suggested by arbitration centres as well as by International Chamber of Commerce arbitration practice. The UNCITRAL Model Law (2008 art, 20) specifies that if the place of arbitration has not been determined directly or indirectly by the parties, contemporary arbitration laws make provisions for the arbitral tribunal to determine the seat of arbitration.

\subsection{The role of arbitration in resolving disputes in international carriage of goods}

With regards to international carriage of goods, arbitration clauses serve as a consensual means of settling disputes. Filip (1992) believes that arbitration is seen as being effective not only because it saves time and cost, but also because awards can be enforced on multiple jurisdictions pursuant to the 1958 New York convention on the recognition and enforcement of foreign arbitral awards. Arbitrations are favoured than formal legal systems because the disputing parties may desire to maintain secrecy about the nature of their transaction to avert the prying eyes of the government who may misinterpret the intricacies surrounding such transaction. In addition to this, the option of using industry experts who are conversant with such intricacies as arbitrators rather than traditional state court judges; as well as the ability given to parties to settle a dispute whilst maintaining business relations are taken into context by parties while drafting contract for the carriage of goods.

Disputes between parties in international carriage of goods may arise from a breach of contract exemplified by damaged goods, short delivery or loss of goods. The severity of such scenario is further exacerbated by problems of jurisdiction as parties to the contract are not domiciled in the same country (Topaloğlu, 2012). While the buyer may seize the courts of the place of delivery which are generally the courts of his domicile, the carrier may also contest their jurisdiction relying on the choice of court as contained in the bill of lading (Topaloğlu 2012). In the same vein, Gaffney (2018) states that given the complex nature of transport disputes which is guided by a specialized set of laws and rules, parties may be caught up in litigation which may stretch for years with several stages of appeal

One of such cases is Burns Philp (South Seas) Company ltd vs Marine Pacific ltd. In this case, the plaintiff contracted with the defendant to ship cargo from Suva to Labasa. The carriage which was carried in the deck of a barge was lost as a result of damage to the barge. As recounted in Burns Philp (South Seas) Company ltd vs Marine Pacific ltd [1979] AC [2008] 7 AC 12, the bill of lading was stamped 'cargo carried on deck at shipper's risk without responsibility for loss or damage howsoever caused'. Condition 26 of the bill of lading provided that "all goods shipped at the deck cargo to be carried at owner's risk" (Burns Philp (South Seas) Company ltd vs Marine Pacific ltd [1979] AC [2008] 7 AC 12). The plaintiff claimed a breach of contractual duty on the part of the defendant for failing to ensure that the cargo was properly secured and delivered. The defendant on their part claimed protection of the exclusion clause inserted by the parties in the bill of lading. The dispute which dragged on for years saw the plaintiff's case being dismissed since the bill of lading did stipulate the exemption clause. The plaintiff made an appeal on the grounds that the lower court should have taken a stricter interpretation of the exclusion clause claiming that the defendant failed to prove that it was not guilty of any fundamental breach. This case which dragged on for years is one of such many cases involving disputes emanating from carriage of goods which have been tried in traditional law courts.

\subsection{Juxtaposing arbitration and litigation}

As depicted from the above scenario and replicated in other disputes of similar nature, litigation can drag on for years, costing both parties valuable time and resources. To prevent the occurrence of such, arbitration clauses have been touted as a panacea to resolving transport disputes. This is because it is cost effective and faster than litigation since there is no appealing the decision (award) of the arbitration which is binding on the parties like that of a traditional court of law (Wolaver 1983). Also, arbitrations cost less than cases in law courts and are presided over by industry experts rather than lawyers that may not be fully knowledgeable about the complexities and intricacies surrounding the business.

Arbitrations are also more lenient in the type of evidence admissible. While a judge in a traditional court would not allow hearsay as evidence, an arbitrator may do such to get a better picture of the dispute at hand. In fact, there have been reported cases where awards have been vacated because the arbitrator did not allow hearsay. In LJL 33rd Street Associates, LLC v. Pitcairn Properties Inc), an American Arbitration Association Award was vacated after a southern district court of New York held that the arbitration had been rendered fundamentally unfair because the arbitrator excluded certain hearsay evidence (U.S. App. LEXIS 15625, 2013\}. Under the Federal Arbitration Act of the United States, it is considered as illegal misconduct if an arbitrator excludes hearsay as evidence. 
Arbitrations as depicted above also resolve the problem of place in international carriage of goods. Arbitrations determine the conflict of laws system which the arbitrators had to apply; the jurisdictions competent to supervise and assist arbitral proceedings; including the domestic or foreign character of arbitral awards with regard to recognition and enforcement proceedings (U.S. Dist. LEXIS 24986, 2012). The ripple effect of this is predicated on the fact that international commercial arbitration would be detached from local laws. As such, arbitrators are not bound by the conflict of laws or procedural rules at the place of arbitration or that the fact local courts at-the arbitral place might intervene with the arbitral process (unless in extreme cases as cited in LLC v. Pitcairn Properties Inc). Also, local courts would be unable to scrutinize arbitral awards rendered in another country in the course of recognition or enforcement proceedings on the basis of the laws applicable in that other territory

Finally, the arbitration clause which is viewed as the principal way of resolving disputes between parties in almost every aspect of international trade and commerce not only helps in preventing long pending disputes with regards to jurisdiction, but also prevents one party from having an upper hand in determining the applicable arbitration law still exists since various arbitration laws exist side by side. The parties to the contract explicitly state where the seat of the arbitration would be domiciled (UNCITRAL Model Law 2008, art. 20) As such, when there is a breach of contract exemplified by damaged goods, short delivery or loss of goods, the parties may seek recourse to the arbitration clause to settle their dispute.

\subsection{Conclusion}

A contract of carriage specifies issues which relate to the safe conveyance of goods from one specified place to another specified place. The essence of the contract is to safeguard that the goods are carried in a safety and also in a timely manner by the carrier. In essence the parties have to agree on the time and place of shipment and delivery, the direction of voyage, the payment of freight, the obligations of the parties in carrying the necessary task of transmitting the goods from the specified place to their destination; the choice of law, choice of arbitration and also the incorporation of charter party clauses (if necessary) and any other matters that might affect the rights and also the liability of the parties.

The contracts for the carriage of goods by sea has been seen to be very enterprising but the legal framework that governs it is both complex, rigid and unpredictable, the life saver to this is when the laws are being harmonized to bring stability and certainty to the laws governing the contract for the carriage of goods by sea, it neutralizes laws and makes it flexible for it to fit into civil and common law. It assumes efficiency in the global allocation of laws that will govern and unify the carriage of goods by sea for less complexity and uncertainty in the arbitration clauses.

A convincing and achievable solution might involve the development of a new model law along the lines of the UNCITRAL Model Laws on Arbitration (2008), which can provide a general standard framework liability regime for adoption by jurisdictions. Within this universal framework, allowances should be made for frequent appraising of the detailed substantive provisions this would ensure that the regime does not fall behind developments. This concept of reform, if properly executed, can help achieve the useful advantages required in adopting hybrid carriage regimes, without losing international uniformity or coherence.

In essence in the inclusion of Arbitration should be a necessity instead of an option, because as a result of the inclusion of the clause, parties are allowed to choose beforehand the Laws that govern their transaction. In the event of disputes they can determine the place of arbitration, necessary laws, and the number of people that would arbitrate over the issue, if all these are stated in the contract, it becomes easier for parties to settle disputes easier and both parties are relatively comfortable with the outcome of the arbitration. Due to the intricacies that are surrounded by carriage of goods the inclusion of the arbitration clauses, would help reduce and sort out the various intricacies that evolve in the transaction. It is also important that arbitration clauses should be clear and precise, because if not clear and precise it has not solved the problem, because the parties would have to first faced with the issue to tackle what exactly the arbitration clause is talking about before going into the crux of the matter, this further delays the dispute settlement and there by negating the inclusion of the arbitration agreement. The inclusion of the clause should be a necessity because it shows clearly that parties have consented to resolve their disputes by arbitration, this consent is very important because it validates the Arbitration.

\section{REFERENCES.}

Czinkota M, Ronkainen I, Sutton-Brady C, \& Beal, T.( 2008) International marketing, Cengage Learning Australia, South Melbourne.

Filip De Ly.(1991) The Place of Arbitration in the Conflict of Laws of InternationalCommercial Arbitration: An Exercise in Arbitration Planning, New Jersey. Journal of Law. \& Business. (12) 48, 91- 102

Gaffney J (2017) 'Transportation Disputes: Can Arbitration deliver the Goods?' Tamimi.com, Available at, https://www.tamimi.com/law-update-articles/transportation-Disputes-can-arbitration-deliver-goods/ Viewed 19 July 2018 
Hovell, D (2018) 'The Authority of Universal Jurisdiction', European Journal of International Law, (29)17, 427

Redfern A, Blackaby N, Partasides C \& Martin H.( 2009)Redfern and Hunter on international Arbitration $5^{\text {th }}$ ed, Cambridge University Press Cambridge

Rousseau, J (2017) On the Social Contract, Reissued edition, OUP Oxford Topaloğlu, B (2012) 'The Validity of Jurisdiction and Arbitration Clauses as Against Third Party Holders of Bills of Lading - a Comparative Study under French, English and Eu Law' Annales, (33) 4, 453

Wolaver, E (1983) 'The historical background of commercial arbitration', University of Pennsylvania law review, (13) 4,138.

\section{Cases}

Burns Philp (South Seas) Company ltd vs Marine Pacific ltd [1979] AC [1979] 3 WLR 1090, Chahal v Lumburd ltd (1996) U.S. App. LEXIS 15625

LJL 33rd St. Assocs. LLC v. Pitcairn Props., 2012 U.S. Dist. LEXIS 24986

Porter v Magill [2002] AC 357

Sierra Fishing \& Ors v Ali Zbeeb \& Ors [2015] EWHC 140

\section{Statutes}

United Nations Convention on Contracts for the International Carriage of Goods Wholly or Partly by Sea (New York 2008) (The Rotterdam Rules)

UNCITRAL Convention on the Recognition and Enforcement of Foreign Arbitral Awards Adopted 10 June 1958

UNCITRAL ' $\mathrm{S}$ discussion of art 78 is reported in $18^{\text {th }}$ session report paragraphs $273,278-279$; $20^{\text {th }}$ session report paragraphs $216-218 ; 21^{\text {st }}$ session report paragraph 232;2008 commission Report 235

United Nations Commission on International Trade Law, Model Law on international Commercial Arbitration (1985) adopted on 21 June 1985 